\title{
Visszatérö talpi fekélyek, osteoneuroarthropathia és sebészi feltárást is igénylő osteomyelitis súlyos fokú distalis szenzoros polyneuropathia következményeként - esettanulmány
}

Körei Anna Erzsébet dr., Putz Zsuzsanna dr., Vági Orsolya Erzsébet dr., Istenes Ildikó dr., Hajdú Noémi, Kempler Péter dr.

\section{Osszefoglalás}

A szerzők közleményükben egy súlyos szenzoros károsodásban szenvedö cukorbeteg esetét ismertetik, akinek szenzoros neuropathiája korán trofikus fekély kialakulásához vezetett. A neuropathia oki kezeléseként alfa-liponsav-adást kezdtek, a megfelelö glykaemiás kontroll mellett a kardiovaszkuláris rizikófaktorok felmérését követöen a beteg antihipertenziv kezelését bövitették, statin-és allopurinolterápia is indult. Az évek folyamán jelentkezö újabb és újabb trofikus talpi fekély perifériás érbetegség hiányában jó gyógyhajlamot mutatott. A beteg neuropathiás eredetü fájdalmai idővel jelentösen fokozódtak, igy a neuropathia oki kezelését tüneti szerrel egészitették ki, mellyel a beteg fájdalmai a továbbiakban jól uralhatóak voltak. A szenzoros neuropathia további szövödményeként Charcot-féle osteoarthropathia, a lábfejek deformitása és kalapácsujj alakult ki, kezelésükre a beteg egyedileg kialakitott, tehermentesitö szilikonbetétet és cipöt használt jó eredménnyel. A beteg utolsó klinikai észlelésének alkalmával a jobb II. lábujj váladékozó fekélye és a distalis lábfej erythemás duzzanata miatt jelentkezett, amelynek hátterében Charcot-láb és ulceratio talaján kialakult krónikus osteomyelitis igazolódott. Többhetes célzott antibiotikus kezelés, a lábujjak tehermentesitése és a distalis phalanx fertözött csontfragmentumainak eltávolitása után a fekély gyógyult, a beteg lábujja megmenthetö volt.

A súlyos fokú szenzoros neuropathia a visszatérö talpi fekélyek és a Charcot-láb legfontosabb kóroki tényezöje. A szerzök esetük kapcsán áttekintik a Charcot-láb és diabetesesekben kialakuló osteomyelitis aktuális kérdéseit, és felhivják a figyelmet arra, hogy a neuropathia megfelelö, a kardiovaszkuláris rizikófaktorokra is kiterjedö komplex kezelésével és a diabeteses láb multidiszciplináris megközelitésével az amputáció megelözhetö.

Kulcsszavak: szenzoros neuropathia, neuropathiás osteoarthropathia, Charcot-láb

\section{Recurrent plantar trophic ulcers, neuro-osteoarthropathy and osteomyelitis requiring surgical debridement as consequences of severe distal sensory polyneuropathy - case report}

Summary: The authors review the case of a diabetic patient with severe sensory impairment leading shortly to foot ulceration. As pathogenetically oriented treatment, alpha-lipoic acid was initiated. Beneath good glycaemic control, his antihypertensive treatment was augmented, statin and allopurinol therapy was introduced as well. During the following years, the patient intermittently presented with new plantar ulcers that healed due to his preserved peripheral perfusion. His neuropathy showed rapid progression including severe hypaesthesia of all sensory nerve types of both lower extremities. The patient's painful neuropathic symptoms substantially increased meantime and symptomatic medication was added on to the combined casual therapy leading to alleviated neuropathic pain. As further consequences of peripheral sensory neuropathy, Charcot-osteoarthropathy and hammer toe deformity developed. Foot deformity was treated with individually designed diabetic shoes and relieving silicon insole achieving good morphologic result. Last summer, the 
patient presented with a wet ulcer of the II. right toe and an erythematous forefoot. These symptoms were proven chronic osteomyelitis evolved on Charcot foot and ulceration. After targeted antibiotic treatment for weeks, off-loading of the toes and removing the infected bone fragments of the distal phalanx, the ulcer healed and the toe could be preserved. Severe sensory neuropathy is the major cause of recurrent plantar ulcers and Charcot foot. The authors assess the current issues on Charcot-foot and diabetic osteomyelitis and should draw attention to the fact that neuropathy combination treatment involving correction of cardiovascular risk factors and multidisciplinary approach could achieve limb survival.

Keywords: peripheral sensory neuropathy, neuro-osteoarthropathy, Charcot foot

\section{Rövidítések}

CGRP: kalcitonin génhez kapcsolt peptid (calcitonin gene related peptide); hsCRP: magas szenzitivitású C-reaktív protein (high sensitivity C-reactive protein); eGFR: becsült glomeruláris filtrációs ráta (estimated glomerular filtration rate); $\mathbf{H b A}_{1 \mathbf{1}}$ : hemoglobin $\mathrm{A}_{1}$; IL-1: interleukin-1; IWGDF: Diabeteses Láb Nemzetközi Munkacsoport (International Working Group on the Diabetic Foot); MRI: mágnesesrezonancia-képalkotás (magnetic resonance imaging); NFkB: nukleáris faktor к B; PET/CT: pozitronemissziós tomográfia (positron emission computer tomography); RANK-L: receptor aktivátor NFKB ligand; SPECT: egyfotonos emissziós tomográfia (single photon emission tomography); TNFa: tumor nekrózis faktor a

A diabeteses láb szindróma a cukorbetegek morbiditásának és mortalitásának jelentős tényezője. Különböző megnyilvánulási formái tekinthetőek a hospitalizáció vezető okának a nyugati országokban a cukorbetegek körében. A teljes 1-es és a 2-es típusú cukorbeteg populációban a talpi fekély élettartam-prevalenciája $25 \%$-ra tehető. ${ }^{1}$

A perifériás szenzomotoros neuropathia többféleképpen járul hozzá a talpi fekélyek kialakulásához. A distalis szenzomotoros neuropathia következtében a betegek számára észrevétlenek maradnak a lábukat érő, kisebb-nagyobb traumák; a láb kisizmainak atrófiája a láb csontjainak, kisízületeinek szubluxálódását, deformitások kialakulását, a talpi nyomáspontok megváltozását idézi elő. A perifériás autonóm neuropathia következményeképpen kifejlődő szudomotor diszfunkció a talp bőrének kiszáradásához, fissurák, rhagadok kialakulásához vezet, ami szintén megteremti a lehetőségét a fekélyek, mélyre terjedő infekciók létrejöttének. ${ }^{2,3}$

A Charcot-féle neuropathiás osteoarthropathia a diabeteses neuropathia egyik, a mai napig jelentôs terápiás kihívást jelentő és csak részben megértett szövődménye. Az osteoneuroarthropathiára jellemző a láb csontjainak dezorganizálódása, fragmentálódása, ami a lábfej progresszív deformitásához vezet. A Charcot-láb egy felmérés sze- rint, bár önmagában nem emeli a cukorbetegekben végzett alsó végtagi amputációk kockázatát, azonban a talpi fekély szövődményes megjelenésével megsokszorozódik a major amputációk rizikója. ${ }^{4}$ A lábközépcsontok Charcot-arthropathiával összefüggő károsodása a talpi fekélyek kockázatának exponenciális emelkedéséhez vezet. ${ }^{5}$ Emellett a neuropathiás osteoarthropathia számottevően rontja a betegek életminőségét és - talpi fekély hiányában is - emeli a mortalitást cukorbetegek körében. ${ }^{6,7}$

\section{Esetismertetés}

A 65 éves férfi beteg kórelőzményében tizennyolc éve ismert, orális antidiabetikummal kezelt 2-es típusú diabetes és hypertonia szerepel. 1995-ben, majd 2008-ban bal oldali calcaneus-sarkantyú miatt sugárkezelésben részesült.

2009 januárjában derült fény a beteg hypaesthesiás típusú perifériás szenzoros neuropathiájára. Ekkor már hosszú hónapok óta észlelte, hogy lábujjai, a lábfejek talpi része érzéketlenné vált, és több alkalommal előfordult, hogy otthonában papucsban sétálva egyszer csak azt észlelte, hogy a papucs már nincs a lábán, vagy rosszabb esetben elbotlott. 2008 novembere óta a jobb halluxon egy $3 \mathrm{~cm}$ átmérőjű trofikus talpi fekély is fennállt. A betegnek fájdalmas tünetei nem voltak, a szenzoros neuropathia negatív tünetegyüttese dominálta a klinikai képet. A klinikánkon Neurometer készülékkel elvég- 
zett vizsgálatok alapján már ekkor súlyos fokú hypaesthesia volt kimutatható, amelynek hátterében a cukorbetegségen kívül egyéb kórállapot nem volt igazolható. Oki kezelésként alfa-liponsav került bevezetésre, a beteg antihipertenzív kezelését bővítettük, hyperlipidaemiára való tekintettel statin-, hyperuricaemia miatt allopurinol-terápiát kezdtünk. A beteg esetében a perifériás artériás pulzusok jól tapinthatóak voltak, számottevő atherosclerosis alsó végtagi Doppler-vizsgálat során sem volt kimutatható (a boka-kar index értéke jobb oldalon 1,09, bal oldalon 1,11 volt). A calcaneus-sarkantyúk kapcsán készült röntgenfelvételeken korábban leírt meszesedés az alsó végtagi artériák falában ennek alapján Mönckeberg-sclerosisnak felel meg, amely a neuropathia részjelenségének tekinthető. A beteg anamnézisében dohányzás vagy rendszeres alkoholfogyasztás nem szerepelt.

A következő két év folyamán a beteg korábbi talpi fekélye gyógyult, neuropathiája azonban további progressziót mutatott: az alsó végtagok mindhárom szenzoros rosttípusa esetében maximális mértékű szenzoros hypaesthesia igazolódott kifejezett mértékű paraszimpatikus autonóm neuropathia mellett. A Neurometer-vizsgálat és a kardiovaszkuláris reflextesztek eredményét az 1. és 2. táblázat tartalmazza. 2011 végére a beteg dominálóan éjszakai, neuropathiás eredetủ fájdalmai jelentősen fokozódtak, elsősorban a lábujjak szúró jellegủ fájdalmát és a lábfej zsibbadását panaszolta. A jobb hallux distalis percén ismét egy kisebb, 0,5cm átmérőjü, gyó- gyulófélben lévő trofikus fekély volt látható, emellett a beteg fájdalmatlan sérüléseket követően kialakult gyulladásos tünetekről (a lábfej duzzanata, erythema) is beszámolt. Laborvizsgálatai során enyhén emelkedett hsCRP-érték (15 mg/l) és gyorsult süllyedés $(58 \mathrm{~mm} / \mathrm{h})$ volt észlelhető, leukocytosis nem volt. A gyorsult süllyedés hátterében a laboratóriumi és képalkotó vizsgálatok nem utaltak malignitásra. A neuropathia kombinált (liponsav + B-vitamin-készítmény) oki kezelését tüneti szerrel (gabapentin) egészítettük ki, amire a beteg fájdalmai a továbbiakban fokozatosan megszűntek. A beteg jobb halluxáról készült röntgenfelvétel már csontreszorpciót és corticalis destrukciót ábrázolt, ami kezdődő Charcot-féle neuropathiás osteoarthropathiára utalt. A beteg a fekélyek ellátására rendszeresen mozgásszervi rehabilitációs ambulancián jelentkezett, a nyomáspontok tehermentesítésére egyedi diabeteses gyógycipővel látták el.

2013 nyarán a jobb II. lábujjon serosusan váladékozó, a bal II. lábujjon kezdődő apróbb fekély, illetve a jobb oldalon kalapácsujj alakult ki, ezek kezelésére a beteg egyedileg kialakított, tehermentesítő szilikonbetétet használt jó eredménnyel.

A beteg legutóbbi klinikai észlelésének alkalmával a jobb II. lábujj váladékozó fekélye és a distalis lábfej erythemás duzzanata miatt jelentkezett (1. ábra), aminek hátterében a klinikai kép és a lábról készült röntgenfelvétel alapján Charcot-láb és ulceratio talaján kialakult krónikus osteomyelitis igazolódott. A sebalap tenyésztése Streptococcus agalactiae

1. táblázat. Szenzoros neuropathia értékelése. A betegnél súlyos fokú, hypaesthesiás típusú szenzoros polyneuropathia volt kimutatható a Neurometerrel végzett vizsgálat során (Neurotron Inc., Baltimore, USA)

\begin{tabular}{|c|c|c|c|c|c|c|}
\hline \multicolumn{7}{|c|}{ Neurometerrel mért áramérzet-küszöbértékek (mA) } \\
\hline \multicolumn{3}{|c|}{ N. medianus } & & \multicolumn{3}{|c|}{ N. peroneus } \\
\hline Bal & Normál & Jobb & & Bal & Normál & Jobb \\
\hline 3,8 & $1,2-3,98$ & 4,27 & $2000 \mathrm{~Hz}$ & 9,99 & $1,79-5,23$ & 9,99 \\
\hline 0,92 & $0,22-1,89$ & 1,5 & $250 \mathrm{~Hz}$ & 9,99 & $0,44-2,08$ & 9,99 \\
\hline 0,76 & $0,16-1,01$ & 0,95 & $5 \mathrm{~Hz}$ & 9,99 & $0,18-1,70$ & 9,99 \\
\hline
\end{tabular}

2. táblázat. Kardiovaszkuláris autonóm neuropathia. A hagyományos kardiovaszkuláris reflextesztek eredményei

\begin{tabular}{|c|c|c|c|c|}
\hline \multirow{2}{*}{ Vizsgált paraméterek } & \multirow{2}{*}{ Eredmények } & \multicolumn{3}{|c|}{ Referenciatartományok } \\
\cline { 3 - 5 } & & Normális értékek & Határértékek & Kóros értékek \\
\hline Légzési arrhythmia (1/min) & 7 & $\geq 15$ & $11-14$ & $\leq 10 / \mathrm{min}$ \\
\hline Valsalva-hányados & 1,21 & $\geq 1,21$ & $1,11-1,20$ & $\leq 1,10$ \\
\hline $30 / 15$ hányados & 1,34 & $\geq 1,04$ & $1,01-1,03$ & $\leq 1,00$ \\
\hline Handgrip-teszt & 16 & $>16$ & $11-15$ & $<10 \mathrm{Hgmm}$ \\
\hline Orthostaticus hypotonia & 0 & $<10$ & $11-29$ & $<30 \mathrm{Hgmm}$ \\
\hline
\end{tabular}


és Citrobacter koseri infekciót igazolt. Öthetes célzott Sumetrolim antibiotikus kezelés, a lábujjak tehermentesítése és a distalis phalanx fertőzött csontfragmentumainak eltávolítása (phalangectomia) után a fekély gyógyult, a beteg lábujja megmenthető volt. A 2. ábrán a sipolyjárat helyén képzett phalangectomiás nyílás, míg a 3. ábrán a gyógyult állapot látható.

A beteg cukorbetegségét metforminkezelés és diéta mellett mindvégig kiváló glykaemiás kontroll jellemezte, $\mathrm{HbA}_{1 \mathrm{c}}$-érté-

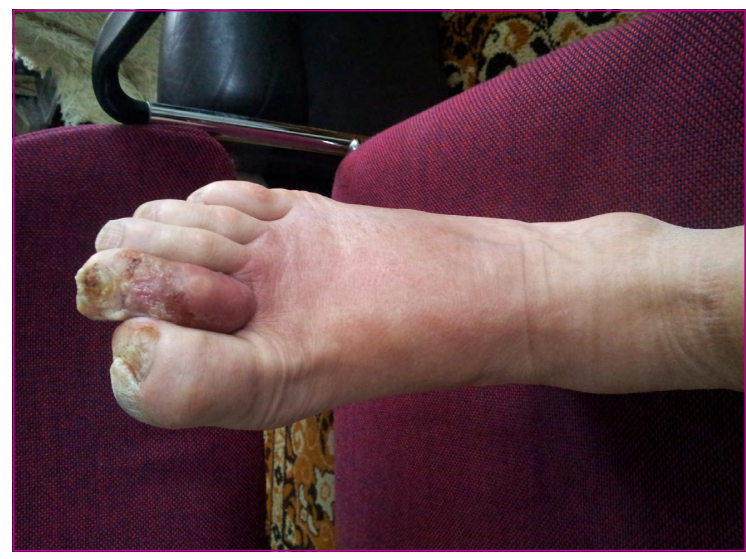

1. ábra. A jobb II. lábujj trofikus fekélye sipolyképzödés útján vezetett betegünk esetében osteomyelitis kialakulásához. A képen jól látható a lábfej erythemás duzzanata, a Il. ujj lágyszöveteiben gennygyülem sejthető

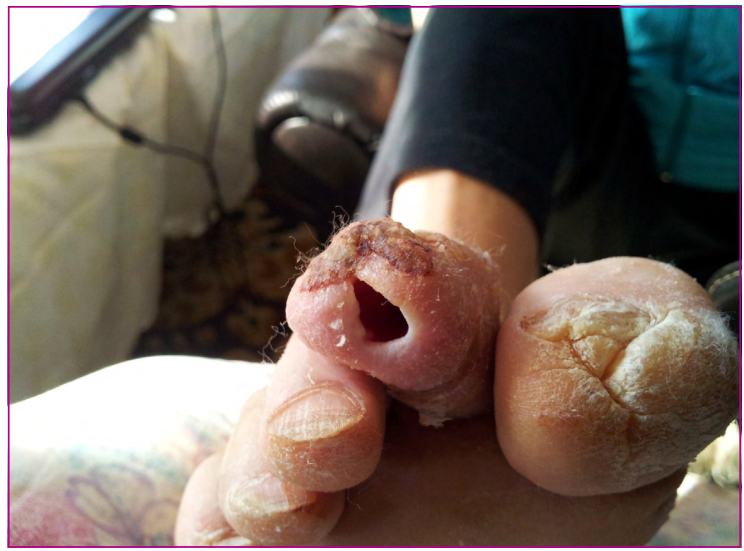

2. ábra. A phalangectomia nyílása, amelyen keresztül a sipoly feltárása és a fertőzött csontfragmentumok eltávolítása történt ke az évek során 5,5\% körül mozgott. Obliteratív verőérbetegség, illetve generalizált osteoporosis a beteg esetében nem volt igazolható. Rendszeres szemészeti kontroll retinopathiának megfelelő eltéréseket nem írt le, a beteg vesefunkciója mindvégig megtartott volt (eGFR $>60 \mathrm{ml} / \mathrm{min}$ ). Az évek folyamán a beteg klinikánkon több alkalommal részesült alfa-liponsav-MgSO4 infúziós kezelésben, a fekélyek, callusok és csontdeformitások ellátása, az osteomyelitis sebészi feltárása mozgásszervi rehabilitációs osztályon történt.

\section{Megbeszélés}

Felmérések szerint a cukorbetegek körében végzett amputációk és talpi fekélyek mintegy fele megelőzhető lenne a veszélyeztetett betegek idejekorán történő felismerésével és megfelelő betegoktatással. ${ }^{2}$ A diabeteses láb kialakulásában az esetek $80 \%$-ában a neuropathia játszik szerepet, a fennmaradó $20 \%$ pedig alapvetően ischaemiás vagy neuro-ischaemiás eredetű. Ennélfogva nem lehet eléggé hangsúlyozni a neuropathia felismerésének és kezelésének fontosságát.

A diabeteses neuropathia - és más microangiopathiás szövődmények - kezelésének és megelőzésének kulcsa a hosszú távon megfelelő glykaemiás kontroll, ahogyan azt a DCCT és UKPDS tanulmányok (és azok utánkövetéses vizsgálatai) mind 1-es, mind 2-es típusú diabeteses betegek

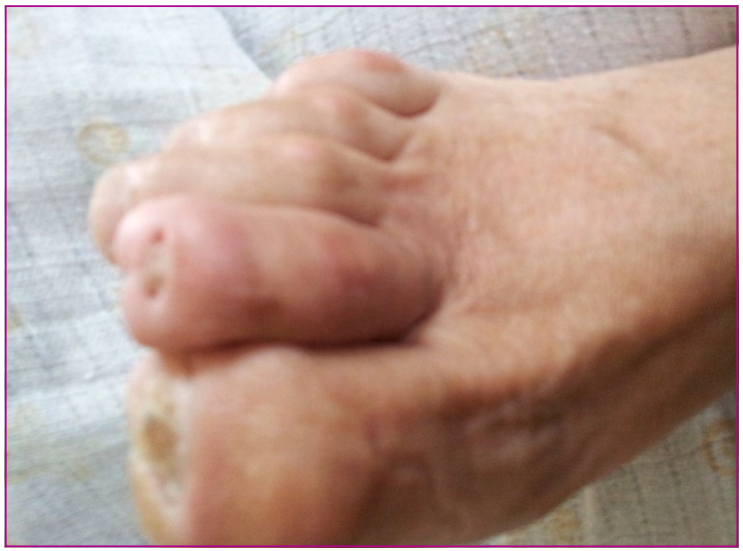

3. ábra. A beteg jobb Il. lábujjának osteomyelitise és az ahhoz vezető trofikus fekély a kombinált konzervatív sebészi és antibiotikus kezelés mellett 2 hónap alatt jó eredménnyel gyógyult 
esetében igazolták. ${ }^{8,9}$ Betegünk diabetesét kiváló glykaemiás kontroll jellemezte, esetében az oki terápia további lehetőségét a kardiovaszkuláris rizikófaktorok feltárása és kezelése jelentette. A perifériás neuropathia és a kardiovaszkuláris kockázati tényezők közötti összefüggés a EURODIAB Complications Study óta bizonyított. ${ }^{10}$ A vérnyomás- és lipidparaméterek rendezése, a trombocitaaggregáció-gátló kezelés egyben a makrovaszkuláris szövődmények megelőzésének is fontos eszköze, az obliteratív verőérbetegség fennállása pedig döntő módon befolyásolja a diabeteses lábinfekciók prognózisát. A diabeteses neuropathia patogenetikai alapokon nyugvó kezelését ma alapvetően a benfotiamin- és alfa-liponsav-tartalmú készítmények jelentik, amelyek - amennyiben a beteg panaszai az indokolják - tüneti szer (elsősorban pregabalin vagy gabapentin) hozzáadásával egészíthetőek ki. Fontos hangsúlyozni, hogy a tüneti szerrel végzett monoterápia a fájdalmas tünetek elfedése mellett magát a kórfolyamatot nem befolyásolja, így az nem ajánlható. ${ }^{11}$

Az akut neuropathiás osteoarthropathiát a lábfej erythemás duzzanata és hőmérsékletének megemelkedése, esetleg fájdalmas járásnehezítettség jelzi. Az emelkedett gyulladásos paraméterek nem kórjelzőek. ${ }^{12}$ A betegek sokszor beszámolnak a gyulladásos tüneteket megelőző kisebb-nagyobb, többnyire fájdalmatlan sérülésről - ez betegünk anamnézisében is fellelhető. A Charcot-láb kialakulásának pontos mechanizmusa nem ismert. Az erek szimpatikus denervációja következtében megnövekedett shuntkeringés, valamint a szenzoros neuropathia miatt ismétlődő észrevétlen traumatizáció a folyamat fő triggerei. Jelentős helyi gyulladásos reakció alakul ki, ami lokális osteoporosishoz, fracturákhoz és akár a lábfej teljes dezorganizációjához vezethet. Régóta ismert tény, hogy Charcot-osteoarthropathia esetén a Mönckeberg-sclerosis előfordulása meghaladja a $90 \%$-ot. ${ }^{13}$ Mind az osteoneuroarthropathiát jellemző osteopeniát, mind a mediacalcificatiót a neuropathiás alsó végtag fokozott perfúziójával hozták összefüggésbe, de csak az utóbbi években merült fel a RANK-L-NFxB jelátviteli útvonal működészavara az eltérések közös magyarázataként. A csont denervációja következtében károsodik a RANK-L, és így az osteoclastok működését gátló CGRP (calcitonin gene-related peptid) és egyéb neuro- peptidek felszabadulása, de a lokális gyulladást kísérő IL-1- és TNF $\alpha$-expresszió is a csontreszorpció irányában hat. ${ }^{14}$ Bár a szenzoros és a perifériás autonóm neuropathia szimmetrikus, mindkét alsó végtagot érintő eltérés, az akut Charcot-láb gyakorlatilag kivétel nélkül csak az egyik végtagon jelentkezik. Az aszimmetria hátterében az érintett végtagot ért minor trauma, korábbi ulceráció vagy sebészi beavatkozás szerepét feltételezik. ${ }^{14}$

A napi klinikai gyakorlatban fontos az osteoneuroarthropathia egyéb, egyoldali erythemás duzzanattal járó kórképektől, mint a csont- és lágyrészinfekcióktól vagy mélyvénás thrombosistól történő elkülönítése. Az egyszerủ röntgenfelvétel igen hasznos lehet az osteoneuroarthropathia diagnosztikájában, bár a kórkép kezdeti stádiumában alacsony szenzitivitással és specificitással rendelkezik, a kórjelző radiográfiai eltérések a betegség progressziójával válnak láthatóvá. Külön problémát jelenhet a Charcot-láb osteomyelitistől való elkülönítése. ${ }^{15} \mathrm{Az}$ MRI a legszenzitívebbnek tartott módszer a korai eltérések kimutatásában, és általában az MRI választandó, amennyiben az osteoneuroarthropathia és/vagy infekció fennállása klinikailag nehezen megítélhetô. További alternatívát jelent ezen esetekben a leukocyta-szcintigráfia vagy SPECT/CT végzése, de PET/CT-vel is vannak ígéretes eredmények. ${ }^{16}$ A komoly technikai fejlődés ellenére fontos szem előtt tartanunk, hogy ezen utóbbi képalkotó eljárásoknak igen jelentős a költségvonzata és korlátozottan állnak rendelkezésre. Andrew Boulton felhívja a figyelmet: a kezdeti diagnózist mindig a klinikai kép alapján kell felállítani és neuropathiás betegben a duzzadt, meleg, kipirult végtagnak mindig fel kell vetnie Charcot-láb gyanúját. Ez esetben pedig az érintett végtag azonnali nyugalomba helyezése (offloading) szükséges. ${ }^{2} \mathrm{Az}$ offloading a Charcot-láb kezelésében a mai napig az egyetlen, bizonyítottan hatásos módszer, amivel kapcsolatban erős klinikai evidencia áll rendelkezésre. Tanulmányok vizsgálták a biszfoszfonátok potenciális szerepét az akut Charcot-folyamatot kísérő csontdestrukció gátlásában, azonban hosszú távú hatásaikkal kapcsolatban nem állnak rendelkezésre meggyőző adatok. ${ }^{17} \mathrm{Az}$ akut fázist követően van lehetőség rekonstrukciós műtétekre, amelyeknek célja a végtag funkciójának helyreállítása, illetve a szekunder ulcerációk megelőzése. 
$\mathrm{Az}$ osteomyelitis a diabeteses láb enyhe infekcióinak 10-12\%-áért, míg a súlyos fertőzések 50\%áert felelős. Osteomyelitis fennállására kell gondolnunk, ha egy trofikus fekély megfelelő, a láb tehermentesítését is magában foglaló kezelés ellenére 6 héten túl nem gyógyul. ${ }^{18} \mathrm{~A}$ szakirodalomban gyakran hangsúlyozzák, hogy a Charcot-láb inkább neuropathia, míg osteomyelitis inkább macroangiopathia talaján fejlődik ki. A fentiekben ismertetett betegben perifériás érbetegség nem volt kimutatható, így az osteomyelitis kialakulását nem a rossz vérellátású vagy devitalizált szövetek segítették elő. Ez esetben a Charcot-lábat jellemző csontdeformitások és a megváltozott nyomáspontok miatt kialakult visszatérő fekélyek vezettek idővel a csontra vezető sipoly és csontinfekció kialakulásához. Az eset arra is felhívja a figyelmet, hogy az osteoneuroarthropathia és az osteomyelitis egyidejűleg is fennállhat.

A diabeteses lábban kialakuló osteomyelitis kezelését érintő legtöbb vita az antibiotikus és a sebészi kezelés relatív súlyával kapcsolatos. A retrospektív elemzések értékelését és összehasonlíthatóságát nehezíti, hogy az osteomyelitis diagnózisa sokszor nem szövettanon, hanem a klinikai megítélésen alapul, illetve hogy az egyes szerzők mást és mást tekintenek „gyógyult osteomyelitisnek". Sanchez véleménye szerint csak az az osteomyelitis tekinthető maradéktalanul gyógyultnak, ahol ép bőr borítja a csontfelszínt, tehát a fekély is begyógyult. ${ }^{18}$ Egyes szerzők az antibiotikum-terápia elsődlegessége mellett foglalnak állást. ${ }^{19,20}$ Megjegyzendő azonban, hogy ezen vizsgálatok egyikében a későbbi térd alatti amputációk aránya a $30 \%$-ot is elérte, ${ }^{20}$ míg a másikban az antibiotikus terápia medián tartama $40 \pm 30$ hétre $^{19}$ nyúlt. Egy tanulmányban a mütéti kezelést megelőző, hosszan tartó antibiotikum-terápia esetén magasabb amputációs rátát találtak. A jelenség hátterében a szerzők a rezisztens baktérium-törzsek kiszelektálódásának szerepét feltételezik. ${ }^{21}$ Másrészről a maior amputációkat az életet veszélyeztető, súlyos infekciók, illetve a súlyosan ledált keringésű végtagok ellátására kell fenntartani, amikor revaszkularizáció nem jön szóba. ${ }^{22}$

A rendelkezésre álló adatok alapján úgy tünik, hogy a célzott antibiotikum-terápia a fertőzött csontfragmentumok és devitalizált lágyrészek eltávolításával kombinálva az esetek többségében az osteomyelitis gyógyulását eredményezi. ${ }^{18} \mathrm{Ez}$ utóbbi jelenti az osteomyelitis „konzervatív” sebészi megközelítését. Sanchez és mtsai több mint 110 osteomyelitisben szenvedő diabeteses beteg esetét dolgozták fel, és az azonnali amputációt igénylő súlyos esetek kizárását követően azt találták, hogy a korai konzervatív sebészi kezelésben (phalangectomia, metatarsus-resectio, exostectomia stb.) részesült betegek körében mindössze az esetek 18\%ában volt szükség további amputációra, és ebből a maior amputációk aránya 6,3\%-nak adódott. ${ }^{23}$ Betegünk esetében phalangectomia történt, tehát a jobb II. ujj distalis percének csontja került több ülésben eltávolításra, öthetes célzott, mikrobiológiai diagnózison alapuló antibiotikum-kúra mellett a lábujj jó morfológiai és funkcionális eredménynyel gyógyult. Fontos ezen a ponton ismét hangsúlyozni, hogy a beteg esetében jó alsó végtagi perfúzió az osteomyelitis gyógyulása szempontjából döntő jelentőségủ volt. Alsó végtagi keringészavar fennállása esetén az érintett végtag korai revaszkularizációja szignifikánsan csökkenti az amputáció valószínűségét. ${ }^{21} \mathrm{Az}$ alsó végtagi perfúzió értékelése esszenciális minden diabeteses betegben.

A diabeteses láb osteomyelitise kapcsán további, kevéssé tisztázott kérdés az antibiotikum-terápia időtartama. Hagyományosan a kezelés parenterálisan kezdődik és legalább négy hétig tart: e megközelítéssel kapcsolatban azonban nem áll rendelkezésre erős klinikai evidencia. Az IWGDF jelenlegi ajánlása szerint, amennyiben nem történik csontresectio, az antibiotikum-terápia időtartama általában 3-6 hónap, de legalább két hónap. Ha minden fertőzött csont eltávolításra kerül, jóval rövidebb idő, akár 2-14 nap is elegendő. A 6 hetet meghaladó kezelés, illetve azon belül az egy hétnél tovább parenterálisan adott antibiotikum nem javítja a kimenetelt. ${ }^{24}$ Konszenzus van abban, hogy az empirikus terápiát a feltisztított sebalapból vagy a fertőzött csontból vett szövetminta mikrobiológiai tenyésztése alapján kell célzott terápiára váltani. Az empirikus terápia tekintetében nincs egyetlen ajánlott antibiotikum vagy egyetlen preferált kombináció, a leggyakrabban a $\beta$-laktám+ $\beta$-laktamáz-gátlókat, cefalosporinokat, fluorokinolonokat és a clindamycint használják. Közepesen súlyos, súlyos fertőzésben a metronidazol kombinációban történő alkalmazása kitűnő kiegészítés lehet anaerob spektruma miatt. A be- 
tegünk esetében alkalmazott sulfomethoxazol/trimetoprim ( \pm rifampi[ci]n) szintén az ajánlott antibiotikumok között szerepel, mivel nagyon jó a biohasznosulása és a csontszövetben nagy lokális koncentrációt ér el. ${ }^{24}$

A fentiek alapján jól látható, hogy a diabeteses láb sikeres ellátásához a társszakmák (belgyógyász-diabetológus, érsebész, ortopéd sebész és technikus, podiáter, diabetológiai szakasszisztens és edukátor, mikrobiológus stb.) és természetesen a beteg szoros együttműködése szükséges. Fontos hangsúlyozni, hogy a beteget, akinek kórtörténetét ismertettük, rendkívül jó compliance jellemzi, lábát naponta maga ellenőrzi, ápolja.

Esetünk jól példázza, hogy bár a Charcot-féle neuropathiás osteoarthropathia progresszív kórkép, de a neuropathia megfelelő, a kardiovaszkuláris rizikófaktorokra is kiterjedő komplex kezelésével és a diabeteses láb multidiszciplináris megközelítésével az amputáció megelőzhető, a végtag funkciója megőrizhető.
Irodalom

1. Singh N, Armstrong DG, Lipsky BA: Preventing foot ulcers in patients with diabetes. JAMA 2005; 293(2): 217-228. doi:10.1001/jama.293.2.217

2. Markakis K, Bowling FL,Boulton AJ: The diabetic foot in 2015: an overview. Diabetes Metab Res Rev 2016; 32(Suppl 1): 169-178. doi:10.1002/dmrr.2740

3. Körei AE, Putz Z, Istenes I, Németh N, Martos T, Kempler M, et al:: A vékonyrostneuropathia klinikai jelentôsége diabetes mellitusban. Diabetologia Hungarica 2014; 1: 15-23.

4. Sohn MW, Stuck RM, Pinzur M, Lee TA, Budiman-Mak E: Lower-extremity amputation risk after charcot arthropathy and diabetic foot ulcer. Diabetes Care 2010; 33(1): 98-100. doi:10.2337/dc09-1497

5. Boyko EJ, Ahroni JH, Stensel V, Forsberg RC, Davignon DR, Smith DG: A prospective study of risk factors for diabetic foot ulcer. The Seattle Diabetic Foot Study. Diabetes Care 1999; 22(7): 1036-1042. doi:10.2337/diacare.22.7.1036

6. Pakarinen TK, Laine HJ, Mäenpää H, Mattila P, Lahtela J: Long-term outcome and quality of life in patients with Charcot foot. Foot Ankle Surg 2009; 15(4): 187-191.

7. Sohn MW, Lee TA, Stuck RM, Frykberg RG, Budiman-Mak E: Mortality risk of Charcot arthropathy compared with that of diabetic foot ulcer and diabetes alone. Diabetes Care 2009; 32(5): 816-821. doi:10.2337/dc08-1695

8. The Diabetes Control and Complications Trial Research Group: The effect of intensive treatment of diabetes on the development and progression of longterm complications in insulin-dependent diabetes mellitus. N Engl J Med 1993; 329(14): 977-986.

9. UK Prospective Diabetes Study (UKPDS) Group: Intensive blood-glucose control with sulphonylureas or insulin compared with conventional treatment and risk of complications in patients with type 2 diabetes (UKPDS 33). Lancet 1998; 352(9131): 837-853.

10. Tesfaye $S$, Stevens $L K$, Stephenson JM, Fuller JH, Plater $M$, lonescu-Tirgoviste C, et al: Prevalence of diabetic peripheral neuropathy and its relation to glycaemic control and potential risk factors: the EURODIABIDDM Complications Study. Diabetologia 1996; 39(11): 1377-1384. doi:10.1007/s001250050586

11. Várkonyi T, Putz Z, Keresztes K, Martos T, Lengyel C, Stirban A, et al.: Current options and perspectives in the treatment of diabetic neuropathy. Curr Pharm Des 2013; 19(27): 4981-5007. doi:10.2174/13816128113199990310

12. Petrova NL, Edmonds ME: Acute Charcot neuro-osteoarthropathy. Diabetes Metab Res Rev 2016; 32(Suppl 1): 281-286. doi:10.1002/dmrr.2734

13. Clouse ME, Gramm HF, Legg M, Flood T: Diabetic osteoarthropathy. Clinical and roentgenographic observations in 90 cases. Am J Roentgenol Radium Ther Nucl Med 1974; 121(1): 22-34.

14. Jeffcoate W: Vascular calcification and osteolysis in diabetic neuropathyis RANK-L the missing link? Diabetologia 2004; 47(9): 1488-1492. doi:10.1007/s00125-004-1477-5

15. Ergen FB, Sanverdi SE, Oznur A: Charcot foot in diabetes and an update on imaging. Diabet Foot Ankle. 2013 Nov 20; 4. doi: 10.3402/dfa.v4i0.21884 (ePub).

16. Leone A, Cassar-Pullicino VN, Semprini A, Tonetti L, Magarelli N, Colosimo C: Neuropathic osteoarthropathy with and without superimposed osteomyelitis in patients with a diabetic foot. Skeletal Radiol 2016; 45(6): 735-754. doi:10.1007/s00256-016-2339-1

17. Richard JL, Almasri M, Schuldiner S: Treatment of acute Charcot foot with bisphosphonates: a systematic review of the literature. Diabetologia 2012; 55(5): 1258-1264. doi:10.1007/s00125-012-2507-3

18. Aragón-Sánchez J: Treatment of diabetic foot osteomyelitis: A surgical critique. Int Jow Extrem Wounds 2010; 9(1): 37-59. doi:10.1177/1534734610361949

19. Embil JM, Rose G, Trepman E, Math MC, Duerksen F, Simonsen JNet al: Oral antimicrobial therapy for diabetic foot osteomyelitis. Foot Ankle Int 2006; 27(10): $771-779$. 
20. Bamberger DM, Daus GP, Gerding DN: Osteomyelitis in the feet of diabetic patients. Long-term results, prognostic factors, and the role of antimicrobial and surgical therapy. Am J Med 1987; 83(4): 653-660. doi:10.1016/0002-9343(87)90894-1

21. Henke PK, Blackburn SA, Wainess RW, Cowan J, Terando A, Proctor M, et al.: Osteomyelitis of the foot and toe in adults is a surgical disease: conservative management worsens lower extremity salvage. Ann Surg 2005; 241(6): 885-892. doi:10.1097/01.sla.0000164172.28918.3f

22. Frykberg RG, Wittmayer B, Zgonis T: Surgical management of diabetic foot infections and osteomyelitis. Clin Podiatr Med Surg. 2007; 24(3): 469-482.

23. Aragón-Sánchez FJ, Cabrera-Galván JJ, Quintana-Marrero Y, HernándezHerrero MJ, Lázaro-Martínez JL, García-Morales E, et al: Outcomes of surgical treatment of diabetic foot osteomyelitis: a series of 185 patients with histopathological confirmation of bone involvement. Diabetologia 2008 51(11): 1962-1970. doi:10.1007/s00125-008-1131-8
24. Lipsky BA, Aragón-Sánchez J, Diggle M, Embil J, Kono S, Lavery L, et al.: IWGDF guidance on the diagnosis and management of foot infections in persons with diabetes. Diabetes Metab Res Rev 2016; 32(Suppl 1): 45-74. doi:10.1002/dmrr.2699

Közlésre érkezett: 2017. március 1. Közlésre elfogadva: 2017. május 18.

A szerzö levelezési címe:

Dr. Körei Anna Erzsébet

Semmelweis Egyetem, I. Belgyógyászati Klinika

1083 Budapest, Korányi S. u. 2/A

E-mail: anna.korei@yahoo.com

\section{A Magyar Diabetes Társaság és a 77 Elektronika 2017. évi Ifjúsági Pályázata}

A Magyar Diabetes Társaság és a 77 Elektronika Kft. 2017. évi Ifjúsági Pályázatára összesen 13 pályázati anyag érkezett. Az MDT vezetősége által kijelölt ad hoc bizottság számára megkönnyítette a döntést, hogy a Magyar Diabetes Társaság idén is több, párhuzamos pályázati lehetőséget biztosított az EASD-re utazni vágyó kollégáknak. A Bizottság kiemelten értékelte a megpályázott kongresszusra küldött absztrakt, illetve a korábban elnyert MDT-támogatások meglétét.

A pályázati kiúrásban szereplő szempontok figyelembevételével dr. Jenei Kinga (Semmelweis Egyetem ÁOK, I. sz. Gyermekgyógyászati Klinika, Budapest) az ISPAD Innsbruckban, a következö kollégák pedig az EASD Lisszabonban megrendezendő éves tudományos ülésére kaptak támogatást: dr. Domján Beatrix, Semmelweis Egyetem AOK, I. sz. Belgyógyászati Klinika, Budapest; dr. Fürst Ágnes, Petz Aladár Megyei Oktatókórház, Győr; dr. Halászlaki Csaba, Szent Margit Kórház, Budapest; dr. Kempler Miklós, Semmelweis Egyetem AOK, III. sz. Belgyógyászati Klinika, Budapest; dr. Körei Anna, Semmelweis Egyetem AOK, I. sz. Belgyógyászati Klinika, Budapest; dr. Molnár Márta, Szaboles-Szatmár-Bereg Megyei Kórházak és Egyetemi Oktatókórház, Jósa András Oktatókórház, Nyíregyháza; dr. Svébis Márk, Semmelweis Egyetem ÁOK, I. sz. Belgyógyászati Klinika, Budapest; dr. Szabó Eszter, Szent Imre Egyetemi Oktatókórház, Budapest; dr. Vági Orsolya Erzsébet, Semmelweis Egyetem ÁOK, I. sz. Belgyógyászati Klinika, Budapest; dr. Veres Agneta, Békés Megyei Központi Kórház, Réthy Pál Tagkórház, Békéscsaba; dr. Lukács Krisztina, Semmelweis Egyetem ÁOK, III. sz. Belgyógyászati Klinika, Budapest; dr. Firneisz Gábor, Semmelweis Egyetem ÁOK, II. sz. Belgyógyászati Klinika, Budapest.

A 77 Elektronika Kft. által évek óta hagyományosan megrendezett Diabétesz Hajó lehetőséget ad az ifjúsági pályázatot elnyerö kollégák számára tudományos eredményeik országos szintủ ismertetésére. Ez évben a rendezvény Budapesten kerül megrendezésre, 2017. augusztus 25-én. A hagyománynak megfelelöen az idei évben is 3 kolléga (dr. Jenei Kinga, dr. Svébis Márk és dr. Szabó Eszter) mutathatja be előadás keretében az EASD-re küldött absztraktban leírt kutatását.

Ezúton is gratulálunk a nyertes pályázóknak!

Tabäk Gy. Ádám dr. az MDT ifúsági felelóse a Birálóbizottság képviseletében 